\title{
LA VOZ ANTIGUA (ECOS Y RESONANCIAS DEL ITALIANO EN LA LITERATURA LATINOAMERICANA)
}

\author{
THE VOICE OF ANTIQUITY (ECHOS AND RESONANCES \\ FROM THE ITALIAN IN LATIN AMERICAN LITERATURE)
}

\section{GINA SARACENI ${ }^{1}$}

\section{RESUMEN}

El presente trabajo se propone rastrear algunos modos de apropiación y uso de una herencia lingüística, cultural, afectiva extranjera en algunos escritores latinoamericanos contemporáneos. A partir de la idea de la literatura nacional como un espacio de resonancia de otras literaturas y lenguas, me interesa analizar cómo se inserta el legado del italiano en una literatura mayor, a qué representaciones da lugar y cómo el heredero se hace cargo de este legado, cómo lo habita y lo interviene, cómo se posiciona ante este entre-lugar identitario.

Palabras clave: Herencia, lengua, transmisión, deuda, memoria, literatura.

\section{ABSTRACT}

This work proposes to track some of the appropriations and uses of the foreign heritage of linguistic, cultural and affective aspects in contemporary Latin American writers. Starting from the idea of national literature as a space of resonance with other literatures and languages, I am interested in analyzing how the Italian legacy is inserted in a canonical literature, which representations are present and how the heir takes charge of this legacy, how he or she inhabits it and intervenes in it, how it is positioned in an in-between space of identity.

Keywords: Inheritance, language, transmission, debt, memory, literature.

Recibido: 11.10.11. Aceptado: 09.02.12.

${ }^{1}$ Doctora en Letras de la Universidad Simón Bolívar Caracas (2001). Profesora Titular del Depto. de Lengua y Literatura de la Universidad Simón Bolívar. Caracas, Venezuela. E-mail: marea 132000@yahoo.com 
L'uomo solo ascolta la voce antica che i suoi padri, nei tempi, hanno udito, chiara e raccolta, una voce che come il verde degli stagni e dei colli incupisce a sera.

É la voce che un giorno ha fermato il padre del padre, a ciascuno del sangue morto.

Cesare Pavese

\section{LITERATURA Y FILIACIÓN}

$\mathrm{L}$ A LITERATURA ES UN ESPACIO donde las herencias culturales, lingüísticas, literarias se abren paso y circulan dando lugar a múltiples formas de enunciación que muestran la diversidad de voces que la conforman. Esta idea de la literatura como comunidad de legados en disputa y diálogo implica la necesidad de sospechar de las formas de construcción de una determinada literatura nacional, porque pone al descubierto la presencia de otros textos, lenguas, imaginarios que están al costado de los reconocidos como hegemónicos ${ }^{2}$.

América Latina, por ejemplo, puede pensarse como un sistema de citas, un tejido de implantes de distintas procedencias que articulan mapas de sentidos y zonas de tensión, convivencia, intercambio entre diferentes legados que se desterritorializan y traducen unos a los otros.

Jorge Luis Borges, en una conferencia de 1978 titulada "El libro", llama la atención sobre el modo como los países construyen su propia semblanza a partir de figuras e imágenes que se contraponen al modelo identitario reconocido como hegemónico:

... cada país tiene que ser representado por un libro; en todo caso, por un autor que puede serlo de muchos libros. Es curioso - no creo que esto haya sido observado hasta ahora- que los países hayan elegido individuos que no se parecen demasiado a ellos (...).

${ }^{2}$ Es importante destacar que en América Latina los corpus literarios nacionales surgen en sintonía con la organización de los estados nacionales, lo que significa que los textos que integran dicho corpus tienen la función de difundir valores, modelos, roles, capaces de contribuir a la formación de la identidad nacional. Esto supone la activacion de mecanismos de inclusión y exclusión de patrones considerados convenientes o no para la construcción de la nación que se desea. Ahora bien, al costado de este ordenamiento de las textualidades literarias llevado a cabo por el discurso letrado hay otras textualidades que, según Graciela Montaldo, circulan "fuera de las fronteras nacionales, por un efecto de desterritorializacion (fuera del núcleo de valores imaginados como comunes en una cultura, ya sea por su lengua, sus materiales, sus intervenciones directas en la esfera pública o su efecto en los lectores criollos y su búsqueda de lectores extranjeros" (1997: 205). 
Es como si cada país pensara que tiene que ser representado por alguien distinto, por alguien que puede ser, un poco, una suerte de remedio, una suerte de triaca, una suerte de contraveneno de sus defectos. Nosotros hubiéramos podido elegir a Facundo de Sarmiento, que es nuestro libro, pero no; nosotros, con nuestra historia militar, nuestra historia de espada, hemos elegido como libro la crónica de un desertor, hemos elegido al Martín Fierro, que si bien merece ser elegido como libro ¿̇cómo, pensar que nuestra historia está representada por un desertor de la conquista del desierto? Sin embargo, es así; como si cada país sintiera esa necesidad (1980: 20-22).

Esta consideración de Borges llama la atención sobre algunos mecanismos que operan en la construcción de una literatura nacional, mecanismos de desvío, que muestran concepciones de la identidad y del canon nacional muy distintas a la hegemónica que la enrarecen y hacen tambalear.

La presencia de voces y lenguas extranjeras en el cuerpo literario nacional, si bien es una marca constitutiva de la literatura latinoamericana desde la fundación de los estados nacionales, en la actualidad ha adquirido nuevos matices que ponen al descubierto la dificultad, cada vez mayor, de trazar una frontera entre lo propio y lo ajeno, lo nacional y lo extranjero en el ámbito de los corpus literarios.

Ante los constantes procesos de migración y desplazamientos de sujetos, lenguas, culturas, memorias; frente a la circulación cada vez mayor de escritores por fuera de su pertenencia nacional, se hace necesario plantear un concepto de canon nacional menos rígido y más permeable a la pluralidad, al contacto, a la contaminación de los legados (Montaldo habla de "canon efímero" cuando se refiere al caso argentino). Un canon que represente las tensiones existentes entre la tradición hegémonica y aquellas voces menos audibles que la recorren y la reescriben desde un lugar lateral y clandestino.

Ricardo Piglia, uno de los críticos que mayor atención le ha prestado al problema de cómo una literatura usa su herencia cultural, entendida como tensión de elementos propios y ajenos, observa que estas corrientes subterráneas que la recorren activan "los mecanismos de falsificación, la tentación del robo, la traducción como plagio, la mezcla, la combinación de registros, el entrevero de filiaciones" (2000: 36). Es decir, la imagen de una literatura nacional "dispersa y fracturada" a causa de la presencia de otros corpus menores que la intervienen de forma "irreverente" mermando su estabilidad y coherencia ${ }^{3}$.

\footnotetext{
${ }^{3}$ Aquí Piglia alude al ensayo de Jorge Luis Borges "El escritor argentino y la tradición”, donde éste se refiere a la literatura judía, irlandesa y argentina como ejemplos de literaturas que se colocan entre lenguas y culturas.
} 
Siguiendo esta misma línea de reflexión, Sergio Chejfec, en un ensayo sobre la literatura judía, observa lo siguiente: "Una circunstancia similar ocurriría en América Latina, cuya literatura de mayor complejidad y aliento estético no es la imediatamente emblemática, la que se identifica con la mirada exterior, sino aquella que tiende a escribirse sobre la frontera borrosa de las tradiciones culturales, confundiendo las nociones de lo propio y lo ajeno (2005: 124).

A partir de estas consideraciones sobre las deudas que toda literatura tiene con diferentes legados, quisiera leer el modo cómo el canon nacional se hace cargo de las corrientes clandestinas que la atraviesan "zanjando" su coherencia. Esta propuesta implica una idea de canon nacional más inestable y abierta a la incorporación y al reconocimiento de voces excéntricas y menos audibles pero, al igual que las canónicas, representativas de otro modo de narrar la fábula nacional. Más exactamente, me interesa analizar cómo ingresa y circula la tradición italiana en algunas literaturas latinoamericanas; qué efectos produce en la lengua y en el imaginario del continente; cómo desestabiliza la lengua mayor y cómo la lengua mayor da cuenta de la ajenidad que la constituye $e^{5}$.

\section{LA DEUDA DEL HEREDERO}

Roland Barthes, en El grado cero de la escritura (1973), habla de "una obs-

\footnotetext{
${ }^{4}$ A este propósito observa Deleuze: "El multilingüismo no consiste solamente en poseer varios sistemas, cada uno de los cuales sería homogéneo en sí mismo; fundamentalmente en la línea de fuga o de variación que afecta a cada sistema y le impide ser homogéneo. Nada de hablar como un irlandés o un rumano hablarían en una lengua distinta de la suya, sino al contrario, hablar en su propia lengua como un extranjero... todos los contrasentidos son buenos, pero a condición de que no consistan en interpretaciones, sino que conciernan el uso del libro, que lo multipliquen, que creen una nueva lengua en el interior de su lengua. 'Los libros bellos están escritos en una especie de lengua extranjera'(...). Esa es la definición de estilo" (Deleuze y Parnet, 1997: 9). Ricardo Piglia habla de la "extrañeza" como "la marca de los grandes estilos que se han producido en la novela argentina del siglo XX: el de Roberto Arlt y el de Macedonio Fernández. Parecen lenguas exiliadas como la del español de Gombrowicz" (2000: 37); además añade: "las formas cristalizadas de la lengua literaria, las maneras y las manías de los estilos ya convencionalizados anulan cualquier música de la lengua porque en los lugares más oscuros e inesperados se pueden captar los tonos de un estilo nuevo"(Id.: 40).

${ }^{5}$ Deleuze observa que este desequilibrio "excede las posibilidades del habla y accede al poder de la lengua y hasta del idioma. Lo que equivale a decir que un gran escritor se encuentra siempre como un extranjero en la lengua en la que se expresa, incluso cuando es una lengua materna. Llevando las cosas al límite, toma sus fuerzas en una minoría muda desconocida, que solo le pertenece a él. Es un extranjero es su propia lengua. No mezcla otra lengua con su lengua, talla en $s u$ lengua una lengua extranjera que no preexiste. Hacer gritar, hacer balbucir, farfullar, susurrar, la lengua en sí misma" (Deleuze y Parnet, 1997: 153).
} 
tinada remanencia" que cada escritura convoca, de una "memoria segunda que se prolonga en las significaciones nuevas", de "un pasado en suspensión" que siempre reaparece (25). Con estas palabras se refiere a la presencia, en la memoria del sujeto, de una huella/deuda que se reactualiza en el presente a través de la lengua: "Cada hombre es prisionero de su lengua, (...) la primera palabra lo señala, lo sitúa enteramente y lo muestra con toda su historia" (82).

Quiero partir de esta reflexión barthesiana sobre la relación entre memoria y lengua para proponer una lectura de cuatro escritores latinoamericanos de origen italiano -los venezolanos Vicente Gerbasi (Canoabo, 1913-Caracas 1992) y Márgara Russotto (Palermo, 1948), el argentino Roberto Raschella (Buenos Aires, 1930) y el mexicano Fabio Morábito (Alejandría de Egipto, 1955) - con la finalidad de revisar cómo la literatura se hace cargo de una lengua que es a la vez propia y ajena; cómo ésta responde a la interpelación de una lengua que se hereda como mandato hermenéutico y reto semántico; qué imaginarios potencia el residuo lingüístico de un origen que se hereda y cómo se construye una literatura que dialoga con linajes culturales diferentes a los de la literatura nacional.

Se trata de un corpus donde la figura del heredero constituye el punto de articulación de dos lenguas y culturas en disputa; donde el narrador o sujeto poético responde a la deuda que tiene con el legado familiar a través de la escritura, haciendo de la escritura el lugar donde la herencia se conserva, no para repetirla, sino para desarticularla mostrando lo que nunca se vio de ella, "lo que siempre estuvo en la oscuridad" (Derrida).

Los herederos a los que me voy a referir, hijos de inmigrantes italianos, usan la herencia recibida para construir un proyecto literario que da cuenta de otros devenires de la lengua, de otros modos de pertenecer a una lengua y a una cultura fundados en la duda, en la vacilación, en la aproximación siempre insatisfecha al legado inalcanzable, en la apropiación infiel.

\section{LA HERENCIA RETRIBUIDA}

Mi padre, el inmigrante (1945) de Vicente Gerbasi ${ }^{6}$ es un poemario dedicado a su padre, Juan Bautista Gerbasi, nacido "en una aldea viñatera de Italia

\footnotetext{
${ }^{6}$ Vicente Gerbasi fue fundador del grupo Viernes (1937), director de la Revista Nacional de Cultura (1971), diplomático y periodista. Durante su infancia vivió en el sur de Italia y en Florencia entre 1923-1929. Allí terminó los estudios de primaria y de secundaria.
}

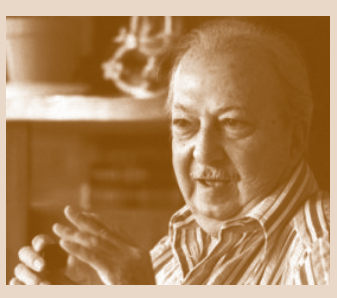

V. Gerbasi 


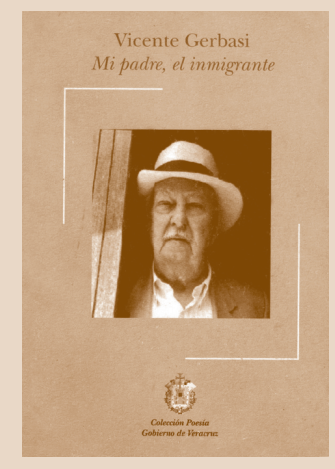

(Vibonati) a orillas del Mar Tirreno", y muerto "en Canoabo, pequeño pueblo venezolano, escondido en una agreste comarca del estado de Carabobo" (Gerbasi, 1986: 63). El hijo intenta responder a la pregunta: "de dónde venimos" a través de un recorrido por los lugares del pasado que la voz paterna relata. El entre-lugar Vibonati-Canoabo que la escritura construye es el espacio donde el hijo interpela al padre; zona de separación y unión, donde dos geografías y culturas -la italiana y la venezolana- se confrontan y endeudan para formar un tercer espacio en el que el "aquí" y el "allá" se vuelven imprecisos e intercambiables. Desde allí el yo poético eleva un canto de despedida y agradecimiento al padre fallecido por el mandato que le transmitió: "por ti soy", "por ti sé" (Id.: 68), "siempre te encuentro, oigo tu voz" (74), "Están en ti mis orígenes,/mis dioses, mis sueños" (86), "mis huellas que vienen de tu vida" (87). El hijo se pone en el lugar de padre y en su nombre recuerda a la "aldea antigua", sus olmos y nogales, sus "callejuelas gastadas de piedras" (69), los pescadores de sardinas, los herreros y pastores, la vendimia, la guerra, las tradiciones navideñas, la época de las cerezas, el sonido de las campanas y de las mandolinas.

Reconocer-se en el padre y escribir en su nombre significa asumir la deuda que el nombre propio tiene con su sangre, con esa "lontananza" que reaparece como "segunda memoria" a lo largo de todo el texto y como llamado que reclama ser escuchado. Hacerse cargo de la "tribu" que constituye al yo y que determina su procedencia y su devenir ("Venimos de la noche y hacia la noche vamos"), significa reescribir el periplo del padre desde su partida de Italia ("Atrás queda la tierra envuelta en sus vapores/..../Atrás quedan los días, con lagos, nieves, renos" (I, 63), hasta su llegada a Venezuela, que aquí representa la promesa de otra vida pero también la decepción que se esconde detrás del viaje: "Cuando tú venías, venías hacia la muerte, / porque así son nuestros pasos en los días" (VIII, 70). Para el hijo reescribir la vida del padre es un modo de inscribir-se en su voz y asumir cómo "la primera palabra" lo "señala" y "lo muestra con toda su historia" (Barthes): "Vienen de ti mi afán y mis palabras / y es tu sangre la que dice con mis labios: / hierro, pan, campana, frente, piedra, flor, caballo/casa, sartén, naranjo, césped, vespertino, / romero, yerba, clavo, cayena y astromelia" (86).

Cabe detenerse en el verso "es tu sangre la que dice con mis labios" porque muestra la dinámica de la adquisición de la herencia: en la medida en que se es fiel al legado recibido, en esa misma medida lo traiciona porque el ejercicio hermenéutico trama un desvío en el original que lo altera y lo hace significar de otro modo, revelando una zona que estaba a oscuras. El hijo no habla como el padre sino como hijo del padre, lo que supone una diferencia entre él y su progenitor, en el sentido de que su herencia no es 
sólo la memoria de Italia con su lengua, sus tradiciones, sus fantasmas, sino también la memoria de la fractura que el viaje imprime en el padre y su estirpe. En este sentido, puede pensarse la poesía como un modo, para el hijo, de retribuirle al padre la herencia recibida; pero esa retribución/interpretación del legado dota al hijo de otro patrimonio: el de la lengua poética ("padre de mi poesía") que le permite acercar las dos orillas que siempre estuvieron separadas y lograr que el "olivo plateado" devenga "melaza", así como el "vino" "aguardiente", sin que ninguno esté al resguardo de un recíproco endeudamiento.

La poesía entonces es una lengua que construye otro lugar, que funda la posibilidad de ser-a-la-vez de dos pertenencias; un espacio donde la traducción da lugar a un texto inédito, en el que el patrimonio es a la vez acumulación e inversión de sentidos y lenguas -la italiana, la venezolana- que transitan una en la otra y que consienten que el hijo le restituya su pasado al padre y se otorgue un relato para el futuro.

\section{LA HERENCIA INAPROPIABLE}

El poemario Épica mínima (1996) de Márgara Russotto ${ }^{7}$ explora de manera fragmentaria y difusa la condición del emigrante italiano en Venezuela a través de poemas donde el desplazamiento y la imposibilidad de pertenecer no sólo forman parte de la herencia recibida sino también son condiciones de la escritura misma.

El libro se abre con una dedicatoria: "A mis padres que lo olvidaron todo y a sus amigos sicilianos que aún recuerdan en vano", en ella llama la atención el deslinde que la autora establece entre el "olvido" de los padres y el recuerdo "en vano" de sus amigos. Esta diferencia sugiere dos modos de posicionarse frente al pasado: uno basado en la amnesia y en la ruptura radical con el pasado; y otro, en la evocación que aquí es "vana" porque, más que restituir el pasado, lo que hace es destituirlo, señalando su ausencia y la inutilidad misma de evocarlo.

La primera sección del libro, titulada "Dibujo de emigrantes", se abre con tres epígrafes que funcionan como claves de lectura del texto porque, de modo diferente, se refieren a la deuda que el sujeto guarda con sus he-

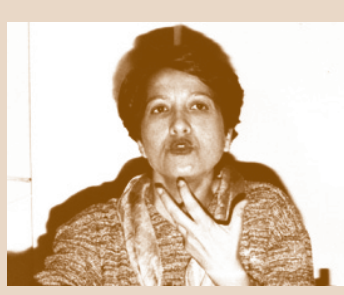

M. Russotto

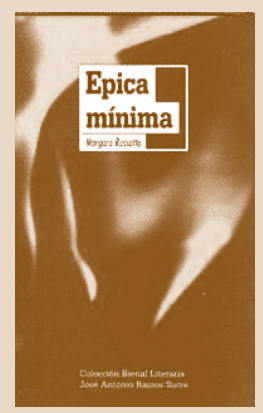

\footnotetext{
${ }^{7}$ Márgara Russotto fue profesora de la Escuela de Letras de la Universidad Central de Venezuela, especialista en teoría Literaria, literatura de género y literatura brasilera, traductora de poetas italianos como Giuseppe Ungaretti, Alfonso Gatto y Giorgio Caproni. Actualmente es profesora en la Universidad de Amherst (Massachusetts).
} 
rencias literarias y afectivas. El primero, de Eugenio Montale, puede verse como un reconocimiento, de parte de Russotto, de la deuda con la tradición poética italiana, además de sugerir la idea del legado como un texto indescifrable que se va volviendo legible ("Tendono alla chiaritá le cose oscure"). El segundo, de Mi padre el inmigrante, funciona como homenaje de la autora a Vicente Gerbasi, al "padre" del linaje literario italiano en Venezuela y como un modo de afiliarse a su mandato. El tercero, de un anónimo chino ("Puedes cambiar de ciudad pero no de fuentes") hace alusión a la imposibilidad de desprenderse de las propias raíces, incluso cuando el sujeto se distancia de ellas.

Epica mínima, a diferencia de Mi padre el inmigrante, donde se observa una voluntad de relatar el viaje paterno de Italia a Venezuela y de aludir a su proceso de adaptación al nuevo país, se aproxima al origen de modo fragmentario, tangencial, sin nombrarlo directamente, sólo lo hace a través de imágenes desenfocadas de una comunidad inmigrante que no logra desprenderse de sus raíces y que reproduce, en sus rituales cotidianos ${ }^{8}$, una Italia fantasmal, enrarecida, difusa. A través de breves menciones a la familia, a la figura de los padres y sus amigos, el yo poético traza la historia de los inmigrantes italianos en Venezuela como una "épica mínima" cuyos protagonistas "nunca cruzaron/el umbral del sacrificio/aferrados al tipo de dignidad/que pone límite/ a la astucia" /(Russotto, 1996: 18). Hombres y mujeres "homéricos, histriónicos" que no lograron desprenderse del "sufrimiento" que traían de sus hogares, "no supieron hacerle frente a la ventura" (Id.), pero tampoco se rindieron nunca ("nunca el ocio"; "acumulaban oro/y con terror/lo sumergían en vinagre/desconfiando de su uso", Id.) "esperando una oportunidad":

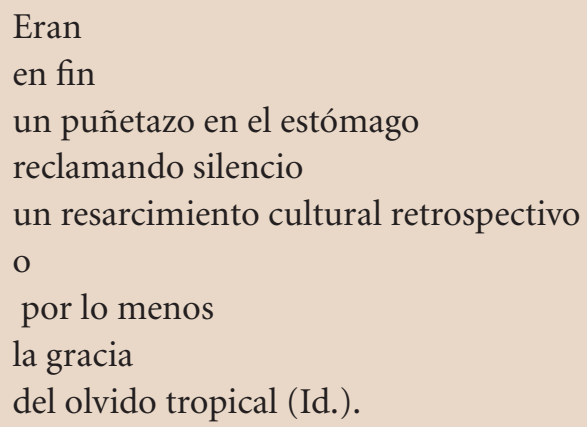

\footnotetext{
${ }^{8}$ En un poema hay una referencia a la costumbre de embotellar salsa de tomate para todo el año, salar sardinas, aderezar aceitunas que son rituales gastronómicos muy comunes en Sicilia (Russotto, 1996: 37).
} 
El viaje se presenta como "fátum", como destino y desgracia, como experiencia incumplida que deja una zona en suspensión, irrealizada, sobre la que la mirada de la heredera afinca su pluma: la resistencia del inmigrante al aprendizaje de otra lengua ("Y jamás sospecharon/el secreto poder de ciertas palabras", Id.), al reconocimiento de otra cultura, pero también su conflictiva relación con el pasado que vuelve como pesadilla más que como nostalgia.

El pasado y el futuro son aquí espacios complementarios de una derrota congénita que se convierte, para el yo poético, en una herencia de la que la poesía se apropia para trazar su ruta: asumir la carencia y el tanteo como procedimientos de una poética "testaruda" que no busca la fijación del sentido sino su desanclaje y movilidad: "Raíces, había?" "Pero de raíces/ ni el recuerdo./ Carecemos" (Id.: 33).

En el poemario de Russotto la herencia del origen también se manifiesta a través de la inscripción de palabras en italiano en la lengua de los poemas que aparecen marcados en cursiva. Esta diferencia parece indicar una brecha que separa la lengua de los padres de la lengua del poema que es también la lengua de la hija: la primera intraducible, inapropiable; la segunda heredada que se distancia del origen para ponerlo en escena como "una irreductible excedencia" de la que es posible apropiarse sólo a través de la renuncia, entendida aquí no como impotencia, sino como aceptación de la dimensión inapropiable de un legado.

\section{LA HERENCIA "MISCITADA"9}

En una línea parecida a la de Russotto se coloca el argentino Roberto Raschella ${ }^{10}$, quien elabora sus ficciones y poemarios sobre los inmigrantes italianos en Argentina a partir de una pregunta relacionada con la lengua literaria y sus modos de apropiarse de otras lenguas. En las novelas Diálogo en

${ }^{9}$ Término del dialecto calabrés; significa mezclar.

${ }^{10}$ Nace el 30 de septiembre de 1930 en Buenos Aires, hijo de inmigrantes calabreses del pueblo de Mammola. Escribe: "Mi padre vino varias veces desde la primera preguerra, hasta que, perseguido por el fascismo, se quedó aquí para siempre en 1925. Mi madre, después de muchas dificultades para poder salir de Italia, llegó en 1929. En un viaje anterior, mi padre se había iniciado en el oficio de sastre. [...] Yo nací en el mes de la revolución del 30. Después llegaron años duros para la familia, nos mudábamos constantemente, siempre a casa con buena luz natural. Era común entonces ver a un sastre trabajando detrás de una ventana”, relata en la entrevista con Pablo Ingberg, en La Nación, Buenos Aires, 1999, en: http://www.audiovideotecaba.gov.ar/areas/ com_social/audiovideoteca/raschella_biblio_es.php

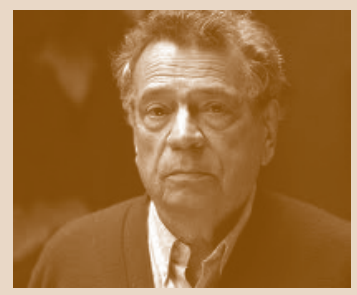

R. Raschella 

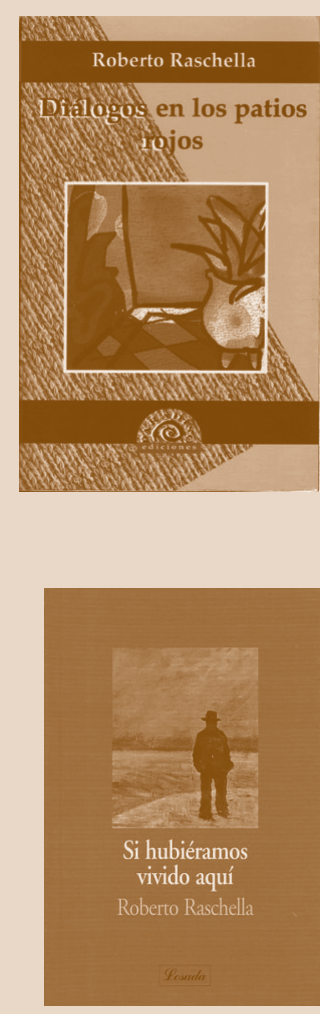

los patios rojos (1994) y Si hubiéramos vivido aquí (1998) y en el poemario Tímida hierba de agosto (2001), cuenta el relato de los padres calabreses que emigran a Buenos Aires en los años 50 y del viaje del hijo al pueblo de origen. Se trata de textos autobiográficos a través de los cuales el autor reflexiona sobre su condición de hijo de inmigrantes, de "emigrado antes de nacer", para quien el desarraigo no es la consecuencia de la ruptura con el lugar natal y el consiguiente proceso de adaptación a un nuevo espacio, sino una condición que se hereda de los padres a través del relato oral que éstos cuentan sobre el "país" de origen. El suyo es un desarraigo de "segunda mano", que es más el efecto del relato sobre el pueblo calabrés contado por los padres que una experiencia vivida directamente, lo que despierta su necesidad de explorar en la "oscura conciencia" familiar, en su "fundamento" para armar la genealogía de sus raíces.

Esta exploración se lleva a cabo a través de la creación de "un objeto lingüístico raro, mezcla del castellano del Río de la Plata con restos vivos del dialecto calabrés" (Sarlo, 1998: 33), capaz de construir una lengua otra que sólo la literatura puede hablar: lengua incomprensible, intraducible, imposible porque en ella las lenguas se alternan sin ninguna "hegemonía lingüística" (Sarlo, 1995: 6): no hay lengua mayor ni lengua menor -independientemente del predominio del castellano sobre el dialecto calabréssino "lengua plural" que habla "en el plural de las lenguas". Lengua incompleta y carente, porque es la falta lo que la hace posible; lengua que habla de la con-vivencia cultural y lingüística que constituye al sujeto emigrante, alegoría expresiva de una condición irresuelta que tiene en la irresolución, la intraducibilidad, la incombinabilidad el atributo más propio ${ }^{11}$. Las dos lenguas que se alternan en el relato ya no pueden hablar desde los márgenes de sus diferencias, sino a partir del intercambio que se genera en esa "zona de vecindad" donde entran en contacto para devenir otras de sí mismas. En ese espacio intermedio de separación y contacto, de negación y multiplicación, de negociación y diferencia, una nueva lengua comienza a hablar, hecha con el remanente de las otras dos, una lengua "necesaria" que halla, en la incompletitud del castellano y el dialecto, la posibilidad de nombrar una identidad que, al igual que la lengua, también es residual: "De todos modos, me parece que es mejor escribir así, como me hablaba la madre, como se gritaba y se murmullaba la paisanada, una lengua 'miscitada' (mezclada) a

${ }^{11}$ Sarlo dice que "el castellano es la lengua de base, pero no es la lengua cuyas reglas deban obedecerse invariablemente. Es un castellano hospitalario con el calabrés, cuyas reglas no son inferiores a la lengua de base... La relación entre ambas lenguas es igualitaria, como es igualitaria la relación entre ambas culturas" (1998: 34). 
otra lengua -y algunas perdían la batalla, o todas perdían la pureza, la virtud de nacimiento" (Raschella, 1994: 189).

Esta lengua surge del trabajo interpretativo que el hijo hace de la herencia recibida; es producto de una intervención del legado que da lugar a otra forma de pertenencia que muestra la pluralidad que la atraviesa:

... aquella barbarie de palabras se elencaba sola, y era como un vicio de abogado defensor, de pastor que recuenta, de tamarro en la escasez del invierno. Y los elencos se cortejaban en visiones bizarras de caballos malados y muros luminosos, cabezas de mártires y húmedas hierbas, fotedores de barbas y lluvias de siroco, que me daban la idea de cocer todo insieme en minestra, y era la cocina que aparecía otra vez, las péntolas de fondo raspado, los platos frantumados como los dientes de Nico, los vasos de culo redondo y opacos, las cortezas de las zucas hervidas y de las frutas mondadas, las pulpas de las sandías abacinantes, los rápidos fermentos de la aguja y la falda. Y los nombres acogían a los verbos, y los verbos colpían en el seño (Id.: 188-189).

Lengua de la simultaneidad y de la opacidad, de idas y vueltas, de memorias y olvidos, de cruces y desvíos. Lengua que la literatura hace posible donde no hay que elegir el "aquí" o el "allá" porque ambos están presentes, cada uno hablando su idioma, en ese plural de la lengua que el heredero construye como apuesta literaria para responder a la deuda con el origen.

\section{LA HERENCIA NÓMADA}

El último autor que me interesa presentar aquí es el escritor mexicano $\mathrm{Fa}-$ bio Morábito, nacido de padres italianos en Alejandría de Egipto (1955); hasta los catorce años vivió en Milán y después emigró con la familia a Ciudad de México, donde reside actualmente ${ }^{12}$. Este desplazamiento geográfico por tres continentes, esta pertenencia a varias lenguas y culturas conforma su identidad biográfica y literaria que se articula a partir de una constante reflexión sobre el desarraigo de la lengua madre y la "naturalidad" de la lengua de adopción, tal como se observa en los poemarios Lotes baldíos (1984), De lunes, todo el año (1992), la plaquette El buscador de sombra (1997) y Alguien de lava (2003).

\footnotetext{
${ }^{12}$ Sobre sus orígenes, Morábito dice: "Soy un italiano nacido en Egipto, algo que siempre me hizo experimentar mi italianidad como raquítica y dudosa” (1993: 23).
} 

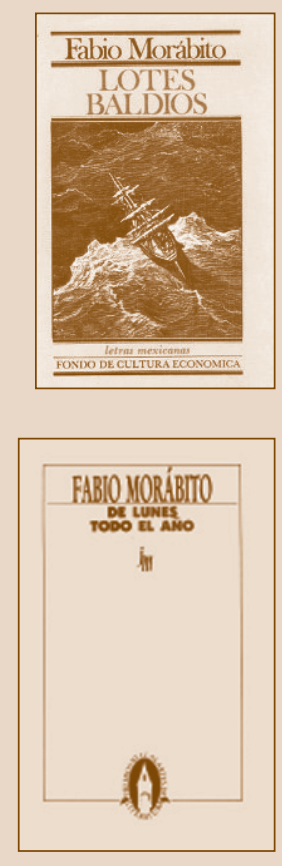

Egipto, Italia, México arman una geografía que es también autobiografía donde la natalidad africana dialoga constantemente con Italia que es la patria que el poeta reconoce como propia: espacio del origen, del árbol genealógico y de lengua madre, pero también lugar de la pérdida, la despedida, del "viaje sin regreso". Con la migración a México, Italia se va desdibujando, perdiendo nitidez y fuerza, como la familia que quedó allí y que se va extinguiendo (ya no "tenemos nada que decirnos") aunque las fotos (de "nuestros hijos") viajen de una a otra orilla para mostrar la continuidad de la sangre (1992: 58) y cómo la lengua se va olvidando:
Ahora,
después de casi veinte años
lo voy sintiendo:
como un músculo que se atrofia
por falta de ejercicio
o que ya tarda
en responder,
el italiano
en que nací, lloré,
crecí dentro del mundo
-pero en el que no he amado
aún-,
se evade de mis manos,
ya no se adhiere
a las paredes como antes,
deserta de mis sueños
y de mis gestos,
se enfría, se suelta a gajos (Id.: 64).

El poeta se encuentra extraviado ante la evidencia de que "ese vaso" que siempre vio "lleno, /inextinguible, /plantado en mí/como un gran árbol,/ como una segunda casa/en todas partes, /una certeza, un nudo /que nadie desataría" (65), se ha desgastado hasta el punto de que ya no puede nombrar el pasado sin traducirlo. De ahí que pierda la naturalidad con la lengua de origen -el italiano- y a la vez se sienta extranjero en la lengua de adopción -el castellano ${ }^{13}$ - Ante esta suerte de orfandad lingüística el poeta se asume como sujeto entre-lenguas lo que significa aceptar el continuo

\footnotetext{
${ }^{13}$ En un ensayo titulado "El escritor en busca de una lengua” (1993), Morábito dice que "sólo es posible hablar otro idioma convirtiéndose en otro individuo" (24). Con ello apunta al hecho de que la lengua es factor constitutivo de la identidad del sujeto y que de ella depende su representación del mundo.
} 
devenir "del idioma de su lengua" en lengua literaria, que nombra no sólo la precariedad e inapropiabilidad del italiano y del castellano, sino también de toda lengua literaria ${ }^{14}$.

Por otra parte, en su obra, Morábito también se refiere a la problemática de la traducción y a su propio proceso de adquisición de una lengua extranjera -el castellano- pero también de la lengua literaria como una "lengua nueva, una lengua extranjera" (Deleuze y Parnet, 1997: 9). El cuento "Los Vetriccioli" del libro La lenta furia (1989b), relato de una familia de renombrados traductores dedicados generación tras generación al oficio de traducir, constituye el marco para una reflexión sobre la lengua, en la que el narrador niega borgianamente la posibilidad de remontarse a un original que sobrevive sólo a través de "distintas capas en un continuo acomodo" (25). Asimismo, se refiere a los idiomas -vivos y muertos-como restos que "no dejará[n] de reaflorar aquí y allá, siempre adherido[s] al subconsciente de la especie" (24), y a la tarea del traductor como "una rehabilitación lenta y caritativa" de la lengua a la que hay que "devolver la salud" (28).

La pasión y la obsesión de los Vetriccioli por traducir, la necesidad de vivir inmersos en las lenguas, buscando los orígenes de las palabras para rescatar significados olvidados y nuevas posibilidades de significación, la encontramos también en muchos poemas de Morábito, donde el hablante poético confiesa que su único oficio es traducir ("Yo no tengo oficio/excepto traducir"(1984: 27)), refiriéndose, a esa "sensación de vivir lingüísticamente en estado precario" (1993: 24) $)^{15}$. En este sentido la "traducción" no es solamente la marca de su condición bilingüe, sino también un ejercicio profesional y estético que elige para despedirse -nunca definitivamente- de la lengua madre ${ }^{16}$ :

Traducir poesía fue una forma de "empezar a poner orden en mis asuntos", (...) ya que en la poesía, como en ningún otro lugar, se compendia la imagen de un idioma y del mundo de ese idioma. Quien se despide

\footnotetext{
${ }^{14}$ Observa Morábito: “Al fin y al cabo la lengua literaria es una lengua extranjera, la más extranjera de todas, la más inasible de todas, porque no tiene referentes fijos ni verdades estables. Cuando creemos que la dominamos es cuando menos la aprehendemos. En otras palabras, no se puede escribir sin una dosis de inexperiencia, de desamparo y de niñez; sin una necesidad oculta de perdón" (2004: 78).

${ }^{15}$ Cabe destacar que Morábito ha traducido varios poetas italianos contemporáneos, entre los cuales Eugenio Montale cuya Obra completa se publicó en Galaxia Gutenberg en el 2004.

16 "El escritor que se expresa en un idioma que no es el suyo es en cierto modo un muerto viviente; adoptar otra lengua significa otorgarse una vida suplementaria, renacer en el seno de una nueva expresividad, pero también enterrar definitivamente otras palabras y otras cadencias" (Morábito, 1993: 23).
} 
de un mundo, se despedirá por último de su poesía, porque la poesía es el postrer saludo que puede lanzar una cultura a quien la abandona, su mensaje más audible a la mayor distancia. Y tal vez la poesía surgió, así, como un arte del saludo y de la despedida. Aquel que pese a la distancia sigue oyendo las voces de la tierra que dejó, es porque ha afinado su oído como lo afina el poeta, que es aquel que condensa el lenguaje y lo desfigura para que alcance su mayor longitud de onda. Pese a todo lo que me ayudó la traducción para cortar el cordón umbilical con mi idioma materno, no he salido, ni creo que nunca saldré, de la franja dudosa a la que me ha relegado mi bilingüismo. En ella se reúnen y dialogan dos idiomas mermados: el materno, por hallarse en continuo proceso de erosión, y el adquirido, porque no logrará jamás hacer desaparecer el fantasma del otro (1993: 24).

En Morábito la deuda con la lengua materna no exige fidelidad; hay en su propuesta poética la conciencia de que la fidelidad a los legados no radica en mantenerlos inalterados, sino más bien en "desfigurarlos", en volverlos a hacer a través de una lengua que sugiera el fantasma de otra, una lengua no desprendida del todo de la materna pero que haya asumido su nueva pertenencia y desde allí dialogue con las voces del origen.

\section{DEUDAS SALDADAS}

Al principio de este artículo planteé la pregunta sobre cómo la literatura se hace cargo de esa "memoria segunda" de la que habla Barthes y sobre cómo leer las trazas de una cultura/lengua secundaria en una literatura nacional.

Los autores aquí analizados muestran, cada uno a su modo, cómo la literatura está atravesada por corrientes extranjeras que abren líneas de fuga en la lengua mayor y que experimentan otros modos de significar.

Cada uno, de manera diferente, pone en escena, cómo circula el fantasma del italiano en sus respectivas literaturas, cómo los interpela y cómo habitan esta condición entre-entrelenguas.

En Gerbasi se observa un heredero que retribuye al padre por la herencia recibida a través de una poesía que se enuncia como compensación de esa deuda y que además logra avecinar Italia y Venezuela a través de una síntesis conciliatoria de sus diferencias. En Russotto hay una heredera que se hace cargo de mostrar el incumplimiento que marca la migración de los padres y cómo ese incumplimiento forma parte del legado recibido: es el mayor patrimonio que hay que custodiar. En Raschella el heredero se coloca en una entrelengua para, desde allí, usar su herencia para volverla 
plural, para transformarla en un plural de lenguas que es el lugar que el hijo del inmigrante habita: ni aquí ni allá sino en ese medio problemático que la literatura hace posible a través de sus devenires. En Morábito hay un heredero más abierto a alejarse del origen y a mirarlo con distancia; un heredero postmoderno que se sabe nómada y que sabe que la pertenencia radica en el desplazamiento constante de las lenguas y las culturas; que no busca ni la fidelidad ni la traición, sino incorporar los materiales de la experiencia a la literatura para dar cuentas del cumplimiento de sus legados y tramas clandestinas.

\section{REFERENCIAS}

Borges, J. L. (1980). Borges oral. Barcelona: Bruguera.

Barthes, R. (1973). El grado cero de la escritura. México: Siglo XXI.

Chejfec, S. (2005). El punto vacilante. Literatura, ideas, mundo privado. Buenos Aires: Grupo Editorial Norma.

Deleuze, G. y Parnet, C. (1997). Diálogos. Valencia: Pre-textos.

Gerbasi, V. (1986). Obra poética. Caracas: Biblioteca Ayacucho.

Montaldo, G. (1997). "Marcar el espacio ajeno: escritores europeos en el Río de la Plata". Estudios. Revista de investigaciones literarias. Año 5, № 9, Caracas, ene-jun., pp. 205-219.

Morábito, F. (1984). Lotes baldios. México: Fondo de Cultura Económica. (1989a). Caja de herramientas. México: Fondo de Cultura Económica. (1989b) La lenta furia. México: Editorial Vuelta.

(1992). De lunes, todo el año. México: Editorial Joaquín Mortiz y Conaculta.

(1993). "El escritor en busca de una lengua". Vuelta, año XVII, N 195, pp. 22-34.

(1995). El pastor sin ovejas. México: Fondo de Cultura Económica. (1998). El buscador de sombra. Sevilla: Ayuntamiento de Carmona. (2000). La vida ordenada. México: Tusquets Editores. (2002). Alguien de lava. México: Editorial Era/ Conaculta.

Morábito, F. (2004). Berlín también se olvida. Barcelona: Tusquets Editores.

Piglia, R. (2000). Crítica y ficción. Buenos Aires: Seix Barral.

Raschella, R. (2001). Tímida hierba de agosto. Córdoba: Alción Editora. (1998). Si hubiéramos vivido aquí. Buenos Aires: Losada. (1994). Diálogos en los patios rojos. Buenos Aires: Ediciones Paradiso.

Russotto, M. (1996). Epica mínim. Caracas: Colección Bienal Literaria José Antonio Ramos.

Sarlo, B. (1995). "Experiencia y lenguaje II". Punto de Vista 51, 5-6.

Sarlo, B. (1998). "Lugar de origen”. Punto de Vista 62, 3-36. 